\title{
高脂血症 の食事療法*
}

一リポ蛋白の変化について——

$\begin{array}{llllll}\text { 横 井順 一** } & \text { 岩 瀬 敬 紀** } & \text { 林 } & \text { 勝 彦** } \\ \text { 佐久間 長 彦** } & \text { 関 知 次 郎*** } & \text { 藤 浪 隆 夫** }\end{array}$

\section{はじめに}

虚血性心疾患をはじめとする動脈硬化性疾患の risk factor として, 血清 pre $\beta$ リポ蛋白 (pre $\beta$-LP), $\beta$ リポ蛋白 ( $\beta$-LP) の増加がとりあげられ，この是 正を目的とした食事療法にはカロリー，コレステ ロール，脂肪の制限が主体として行なわれてきた。 しかし, 近年本疾患とより密接な関係を有する病 態として $\alpha$ リポ蛋白 $(\alpha-\mathrm{LP})$ の低下が明らかにさ $れ^{1,2)}, \alpha$-LP を増加させることによって動脈硬化 の進展を予防しようとする試みが多くなされてい る.

高脂血症の治療としては，まず食事療法が行な われるべきであり，われわれは外来高脂血症患者 に食事療法を行ない，その効果を血清りポ蛋白の 変動より観察した.

\section{方 法}

対象は33歳より69歳までの外来患者で，糖尿病， ネフローゼなど二次性高脂血症の原因疾患を除外 し，少なくとも 3 回以上の採血で血清脂質の動摇 の少ない高脂血症患者42名 (男22名, 女20名) であ る. 血清コレステロール (TC), トリグリセライ ド $(\mathrm{TG})$, リン脂質 $(\mathrm{PL})$ は，それぞれ酵素法で測 定し， $4^{\circ} \mathrm{C}$ で standing testを行なった.リポ蛋白 の定量はすでに報 告3) したごとく, Dyed carbamylated albumin (DC-Albumin)を内部標準物質

* 1979年 2 月, 日本動脈硬化学会昭和53年度冬期大会 において発表

** 名古屋市立大学医学部第 3 内科

*** 同中央検査部
として加えてリポ蛋白電気泳動を行ない，Densitometry により求めた. すなわち, あらかじめ

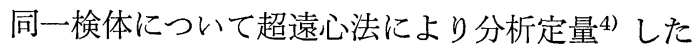
総リポ蛋白と Densitometry により求めた DCalbumin の吸光度\%との関係より得られた回帰式 $\mathrm{y}=8.54 \mathrm{X}-166\left(\right.$ ただし $\mathrm{x}=\frac{1000}{\mathrm{DC}-\text { Albumin吸光度\%})}$ を用いて総りポ蛋白を算出し，それに分画比を掛 け合わせて各リポ蛋白分画值を求めた.

また, 高脂血症分類は WHO の分類 ${ }^{5)}$ に従っ た. 食事療法は Table 1 の基本処方により 5 週間 指導した. すなわち, 具体的な 1 週間の献立を作 成し，これをできる限り忠実に反復させるように し, 期間中は少なくとも 3 回の面接指導し, 内容 その他をチェックした.

\section{結＼cjkstart果}

食事療法による高脂血症タイプの移行を Fig. 1 に示した. 42 例中 9 例 $(21 \%)$ に血清脂質の正常 化を認めている.タイプ $\mathrm{II}_{\mathbf{A}}$ ではタイプの移行は 少ないが，タイプ $\mathrm{II}_{\mathrm{B}}, \mathrm{IV}$ は食事療法による影響 が大きく，それぞれ18例中12 例 $(67 \%), 11$ 例中 7 例 $(64 \%)$ にタイプの移行がみられ, 食事療法後

Table 1 Composition of dietary treatment on hyperlipidemia

\begin{tabular}{lcc}
\hline & IIA & IIB, III, IV \\
\hline Caroly & $30 \mathrm{CAL} / \mathrm{KG}$. & $30 \mathrm{CAL} / \mathrm{KG}$. \\
Carbohydrate & $60 \%$ & $40 \%$ \\
Protein & $20 \%$ & $20 \%$ \\
FAT & $20 \%$ & $40 \%$ \\
P/S Ratio & $>1.0$ & $>1.0$ \\
Cholesterol & $<150 \mathrm{mg}$ & $<150 \mathrm{mg}$ \\
\hline
\end{tabular}




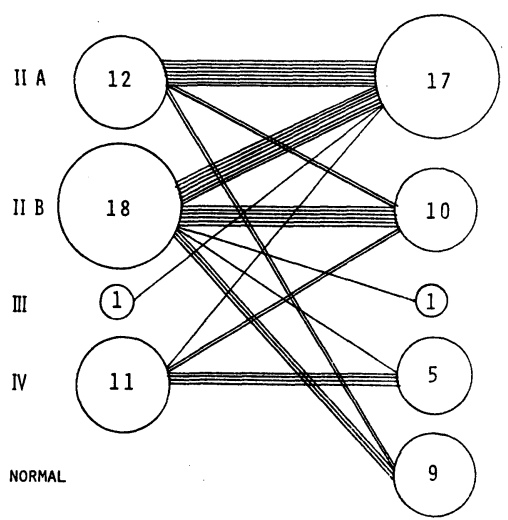

Fig. 1 Changes of lipoprotein phenotype induced with dietary treatment.

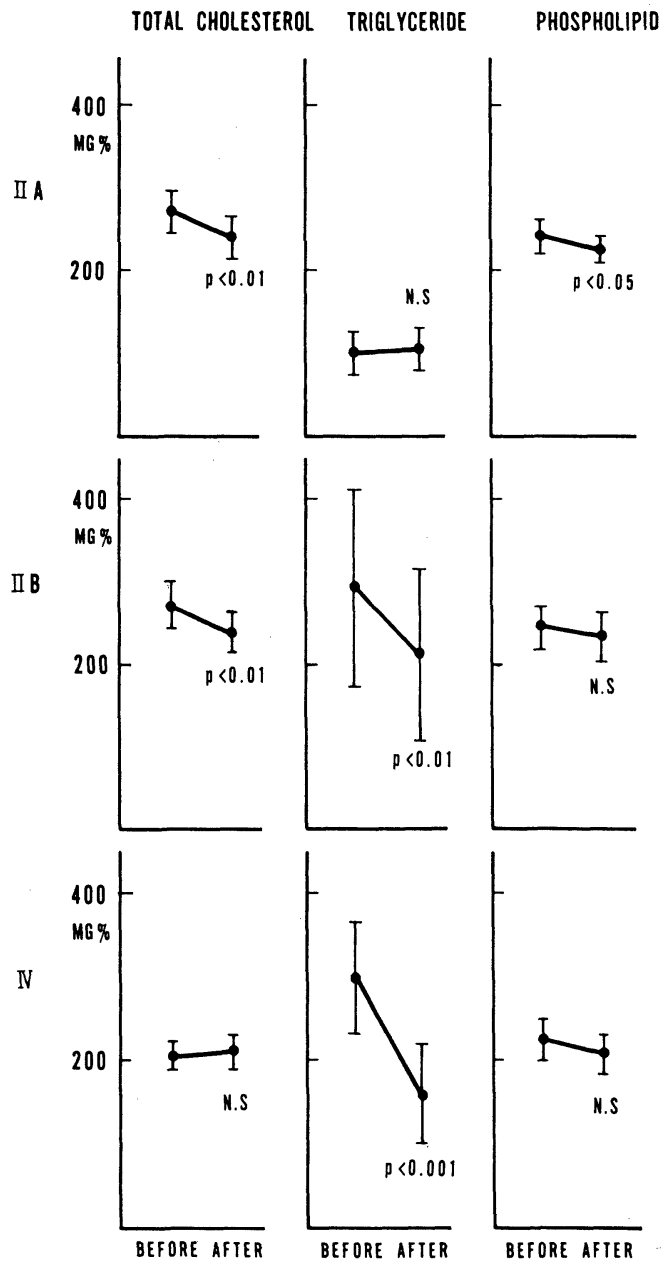

Fig. 2 Changes of serum lipid levels before and after five weeks of dietary treatment.
はタイプII $\mathrm{B}, \mathrm{IV}$ が減少し, タイプ $\mathrm{II}_{\mathrm{A}}$ の増加が みられた. Fig. 2, 3 には各タイプの食事療法前後 の血清脂質とリポ蛋白の変動について対の有意差 検定を示した. タイプ $\mathrm{II}_{\mathbf{A}}$ では血清 $\mathrm{TC}$ が平均 11 $\%(\mathrm{p}<0.01) \mathrm{PL}$ が $5 \%(\mathrm{p}<0.05)$ と低下し， $\alpha$-LP は平均 $8 \%(\mathrm{p}<0.05), \beta$-LP は $10 \%(\mathrm{p}<0.05)$ と 有意の低下がみられた。 タイプ $\mathrm{II}_{\mathrm{B}}$ では血清 $\mathrm{TC}$ が平均 $10 \%(\mathrm{p}<0.01), \mathrm{TG}$ が $28 \%(\mathrm{p}<0.01)$ と低 下し， $\alpha$-LP 住平均 7\% $(\mathrm{p}<0.05), \operatorname{pre} \beta$-LP 35\% $(\mathrm{p}<0.01), \beta$-LP は 14\% $(\mathrm{p}<0.01)$ と有意の低下を 認めた.タイプIVでは血清 TG が平均 $47 \%$ (p $<0.001)$ と低下し, pre $\beta$-LP が平均 $52 \%(\mathrm{p}<$ 0.001) と有意に低下を認めた.

また, 各タイプにおける食事療法前後の $\alpha-\mathrm{LP} /$ $\beta$-LP 比について検討したが，共に有意差は認め なかった。

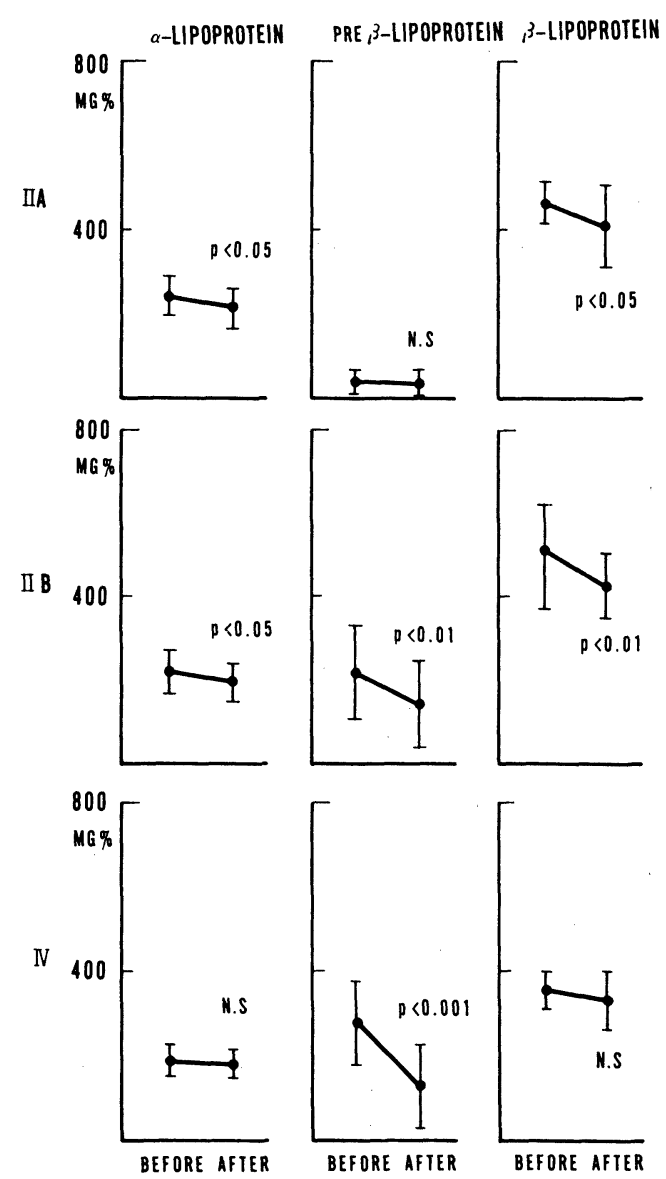

Fig. 3 Changes of serum lipoprotein levels before and after five weeks of dietary treatment. 


\section{考案}

5 週間の食事療法による高脂血症タイプ，血清 脂質およびリポ蛋白の変動を検討した. 42名の高 脂血症患者を通して血清 TC, TG, pre $\beta$-LP, $\beta$-LP は良く低下した. うち9名に正常化を認めた。こ れらのことは対象が外来患者にもかかわらず食事 療法が良く守られたことを示しており，高脂血症 の治療目標として望ましいと考えられる．われわ れの指導している食事療法の基本処方は Table 1 に示したが，できる限り多価不飽和脂肪酸を増す ように工夫し， $\mathrm{P} / \mathrm{S}$ 比は約 3.0 とかなり高いもの となっている.このように食事中のコレステロー ルを減じ, $\mathrm{P} / \mathrm{S}$ 比を高くした食事療法, すなわち New York の Anticoronary club をはじめとした 一連の研究成績から血清脂質の改善がみられ, 虚 血性心疾患の発生が抑えられた事実と, 今回認め た $\alpha$-LP の低下傾向とは, このリポ蛋白のもつ抗 動脈硬化作用を考え合わせると興味深い. 多価不 飽和脂肪酸は以前より食事療法の中心をなしてき たが，その効果と作用に関しては未だ不明の点が 多い。リポ蛋白に対しては, $\beta$-LP, pre $\beta$-LPを低下 させるが, $\alpha$-LP に対しては不変6 8) ないし低下 ${ }^{9)}$ させるとされてきた. 最近 Shepherd ${ }^{10)} ら は \mathrm{P} / \mathrm{S}$ 比を極端に高くするとApo A-I の合成低下がみ られ， $\alpha$-LP の低下を報告している. 今回の成績 でも $\mathrm{P} / \mathrm{S}$ 比が 3.0 では $\alpha$-LP の低下がみられ, 食 事の至適 $\mathrm{P} / \mathrm{S}$ 比も $\alpha-\mathrm{LP}$ との関連で検討すべきで ある.また，タイプIV で $\alpha$-LP に低下傾向がみ られなかったのは, このリポ蛋白と逆相関11)する とされる pre $\beta$-LP の著明な低下が関係している とも考えられる.

\section{まと め}

外来高脂血症患者に食事療法を行ない, 高脂血 症タイプ, 血清リポ蛋白および血清脂質の変動を 検討した. 各タイプとも pre $\beta$-LP, $\beta$-LP が良く
低下したが，タイプ $\mathrm{II}_{\mathrm{A}}, \mathrm{II}_{\mathrm{B}}$ では同時に $\alpha$ - $\mathrm{LP}$ の 低下傾向を認めた。

タイプ $\mathrm{II}_{\mathrm{A}}$ では他のタイプへの移行は少なかっ たが，タイプ $\mathrm{II}_{\mathrm{B}}, \mathrm{IV}$ では食事療法による影響が 大きく，他のタイプへの移行を多く認めた。

\section{文 献}

1) Miller, G. J., and Miller, N. E.: Plasma high density lipoprotein concentration and development of ischemic heart disease, Lancet, 1: 16 (1975).

2) Castelli, W. P., Doyle, J. T., Gordon, T., Hames, C. G., Hjortland, M. C., Hully, S. B., Kagan, A., and Zukel, W. J.: HDL-cholesterol and other lipids in coronary heart disease: the cooperative lipoprotein phenotyping study, Circulation, 55: 767 (1977).

3) 佐久間長彦, 関知次郎, 横井順一, 高田和夫, 藤浪隆 夫: Dyed carbamylated albumin 内部標準法による リポ蛋白電気泳動について, 動脈硬化, 6: 61 (1977).

4) 八杉忠男, 佐々英一, 木下毅, 桑原慎次: 超遠心法 によるリポ蛋白の分析, 最新医学, $27: 424$ (1972).

5) Bearmont, J. L., Carlson, L. A., Cooper, G. R., Fejfar, Z., Fredrickson, D. S., and Strasser, T.: Classification of hyperlipidaemias and hyperlipoproteinaemias, Bull. W. H. O., 43: 891 (1970).

6) Farquhar, J. W. and Sokolow, M.: Response of serum lipids and lipoproteins of man to betasitosterol and safflower oil, Circulation, 17: 890 (1958).

7) Spritz, N. and Mishkel, M. A.: Effects of dietary fats on plasma lipids and lipoproteins; an hypothesis for the lipid-lowering effect of unsaturated fatty acid, J. Clin. Invest., 48: 78 (1969).

8) Vessby, B., Lithell, H., and Gustaffsson, I.B.: Effects of dietary treatment on lipoprotein levels in hyperlipoproteinaemia, Postgrad. M. J., 51: 52 (1975).

9) Nishmann, M. Z., Swelley, C. C., and Olson, R. E.: Plasma fatty acids in normolipemic and hyperlipemic subjects during fasting and after linoleatec feeding, Am. J. Clin. Nutri., 20: 1057 (1967).

10) Shepherd, J., Packard, C. J., Patsch, J. R., Gotto. A. M., and Taunton, O. D.: Effects of dietary polyunsaturated and saturated fat on the properties of high density lipoproteins and the metabolism of apolipoprotein A-I, J. Clin. Invest., 61: 1582 (1978).

11) Wilson, D. E. and Lees, R.S.: Metabolic relationships among the plasma lipoproteins, J. Clin. Invest., 51: 1051 (1972).
質問 山本 章

ことに肥満者における Type の変換, Ch の低 下の場合にはカロリーの方がきいているのか, Ch 制限の方がきいているのか，資料がありましたら
お教え下さい。

\section{回答 横井順一}

体重減少のみらたものでは血清脂質はよく低下 していましたが, 今回のデータからはどちらとは 
いえないと思います。

質問 中島信治 (日本医大老人病研究所, 生化学)

1）食事中の Phospholipid はどのようにしてお られますか?

2）私どもは大豆掠よび大豆製品を多く食べさ せる食事指導で $\alpha$ LPC の増加と $\alpha$ LPPL $(\alpha$ リポ中 の燐脂質）の増加が起こっており，私どもはそれ に本質的な関連を考えています．しかしこの際 $\beta$ リポ分画の燐脂質も多少増加しますので，この点 についても考慮する必要があると考えます。

回答 横井順一

食事中の phospholipids については検討してあ りません。
質問 山崎晴一郎 (久留米大学病態検查学)

Serum の T. Chol. 測定 と $\alpha, \beta$, pre- $\beta$ Lipoprotein を電気泳動で測定していますが, $\beta$-Lipo が増 加している場合, $\alpha$-Lipo の Chol 減少を推測して いるようですが，やはり各 fraction の Chol. TG を測らないと atherogenecity のことがいえないの ではないでしょうか.なぜならば，食事制限をし て，むしろ VLDL で Chol. の增加するものもあ るからです。

回答 横井順一

本研究の目的は, リポ蛋白各分画值の濃度の変 動をみるのを目的としました． 


\title{
Summary
}

\section{Effects of Dietary Treatment on Serum Lipoprotein Levels in Hyperlipidemic Out-Patients}

\author{
Junichi YokoI, Takanori IwaSE, Katsuhiko HaYaShI, Nagahiko SAKUMA, \\ Tomojiro SEKI*, Takao FUJINAMI
}

The 3rd Department of Internal Medicine and Clinical Pathology* Nagoya City University Medical School, Nagoya 467, Japan

On 42 hyperlipidemic out-patients aged 33-69 years, the effects of dietary treatment for five weeks to serum lipoprotein were studied. Two types of diet were designed. Subjects with type IIA were kept on diet low in fat ( $20 \%$ of total carolies) and cholesterol (150 mg daily) and high polyunsaturated/saturated $(\mathrm{P} / \mathrm{S})$ ratio (3.0). Subjects with type IIB, type III and type IV were given a low carbohydrate diet ( $40 \%$ of carolies) and the same content of cholesterol and $\mathrm{P} / \mathrm{S}$ ratio.

Three lipoprotein classes were determined with lipoprotein electrophoresis using an internal standard (dyed carbamylated albumin). The diet caused significant reductions on mean levels of $\alpha$-lipoprotein $(8 \% \downarrow, \mathrm{p}<0.05)$ and $\beta$-lipoprotein $(10 \% \downarrow, \mathrm{p}<0.05)$ in type IIA, $\alpha$-lipoprotein $(7 \% \downarrow, \mathrm{p}<0.05)$, pre $\beta$-lipoprotein $(35 \% \downarrow, \mathrm{p}<$ $0.01)$ and $\beta$-lipoprotein $(14 \% \downarrow, \mathrm{p}<0.01)$ in type IIB and pre $\beta$-lipoprotein $(47 \% \downarrow, \mathrm{p}<0$. .C01) in type IV.

A few cases of type IIA changed into other phenotyre;, but type IIB and type IV changed more frequently into other phenotypes.

Of these, 9 hyperlipidemic patients (21\%) were normalized in the lipid levels.

Key words: Dietary treatment, $\alpha$-lipoprotein, pre $\beta$-lipoprotein, $\beta$-lipoprotein, $\mathbf{P} / \mathbf{S}$ ratio 